\title{
Sulforaphane induces cell cycle arrest and apoptosis in murine osteosarcoma cells in vitro and inhibits tumor growth in vivo
}

\author{
TAKA-AKI MATSUI ${ }^{1,2}$, HIROAKI MURATA ${ }^{1}$, TOMOYA SAKABE ${ }^{1}$, YOSHIHIRO SOWA $^{2}$, \\ NAOYUKI HORIE ${ }^{1}$, RYOKO NAKANISHI ${ }^{2}$, TOSHIYUKI SAKAI ${ }^{2}$ and TOSHIKAZU KUBO ${ }^{1}$ \\ Departments of ${ }^{1}$ Orthopaedics and ${ }^{2}$ Molecular-Targeting Cancer Prevention, Graduate School of \\ Medical Science, Kyoto Prefectural University of Medicine, Kyoto 602-8566, Japan
}

Received June 11,2007; Accepted July 19, 2007

\begin{abstract}
Sulforaphane (SFN), a naturally occurring isothiocyanate, is an attractive agent due to its potent anticancer effects. SFN suppresses the proliferation of various cancer cells in vitro and in vivo. In this study, we report that SFN inhibited the proliferation of cultured murine osteosarcoma LM8 cells. Twenty micromolar SFN completely inhibited the growth of LM8 cells and caused $\mathrm{G}_{2} / \mathrm{M}$-phase arrest. SFN induced the expression of $\mathrm{p} 21^{\text {WAFI/CIPI }}$ protein causing the cell cycle arrest in a dose-dependent manner. SFN induced apoptosis which was characterized by the appearance of cells with sub- $\mathrm{G}_{1}$ DNA content and the cleavage and activation of caspase-3. We showed that SFN induced the growth arrest and up-regulated the expression of $\mathrm{p} 21^{\text {WAFI/CIPI }}$ protein in a p53-independent manner in human osteosarcoma MG63 cells. We found that intraperitoneal administration of SFN ( 1 or $2 \mathrm{mg}, 5$ times/week) significantly inhibited the growth of LM8 xenografts to $<30 \%$ of the controls in a preclinical animal model without causing any toxicity. In osteosarcoma cells, our findings provide in vivo evidence for the efficacy of SFN against the advanced growth of tumor. We showed that SFN induces cell cycle arrest and apoptosis in osteosarcoma cells and inhibits tumor xenograft growth. Furthermore, SFN is a potent inducer of $\mathrm{p} 21^{\text {WAFI/CIPI }}$ in osteosarcoma cells. These
\end{abstract}

Correspondence to: Dr Hiroaki Murata, Department of Orthopaedics, Graduate School of Medical Science, Kyoto Prefectural University of Medicine, Kawaramachi-Hirokoji, Kamigyo-ku, Kyoto 602-8566, Japan

E-mail: murah@koto.kpu-m.ac.jp

Abbreviations: SFN, sulforaphane; GAPDH, glyceraldehyde-3phosphate dehydrogenase

Key words: osteosarcoma, sulforaphane, p21 $1^{\text {WAFI/CIPI }}$, cell cycle arrest, apoptosis, xenografts results raise the possibility that SFN may be a promising candidate for molecular-targeting chemotherapy against osteosarcoma.

\section{Introduction}

Osteosarcoma is a high-grade malignant bone tumor that mainly occurs in juvenile patients. Although the prognosis of these patients have improved substantially through the development of effective adjuvant or neoadjuvant regimens of chemotherapy (1-4), $>20 \%$ of patients still die as a result of tumor metastasis and unresectable tumor (5-10). One of the most serious causes of therapeutic failure is the resistance of the tumor cells to chemotherapeutic agents $(11,12)$. To overcome the drug resistance, identification of novel antitumor agents or chemicals and the development of new anti-tumor therapeutic approaches are urgently required.

One of the causes of cancer is uncontrolled proliferation due to the loss of the checkpoint control associated with the activation of cyclin-dependent kinases (CDKs) responsible for cell cycle progression (13). CDKs, cyclins and CDK inhibitors (CDKIs) are key molecules that play important roles in cell cycle progression (14). p2 $1^{\text {WAFI/CIPI }}$ is a member of the CDKI family and induces $\mathrm{G}_{1^{-}}$and $\mathrm{G}_{2} / \mathrm{M}$-phase cell cycle arrest (15-18). p21 WAFI/CIPI induces differentiation of both normal and transformed cells and suppresses the growth of malignant cells in vitro and in vivo $(19,20)$. Therefore, $\mathrm{p} 21^{\text {WAFI/CIPI }}$ is an attractive molecular target which suppresses cell growth in malignant tumor cells and $\mathrm{p} 21^{W A F I / C I P I}$-inducing agents may be effective for the chemotherapy of poor prognostic osteosarcoma.

Furthermore, cancer cells acquire alternations for enhanced survival and become apoptosis-resistant to anticancer therapies (21). Therefore, the induction of the cell cycle arrest and apoptosis by chemotherapeutic agents can be an effective approach to inhibiting uncontrolled cell proliferation and survival in malignant tumor cells.

Sulforaphane (SFN), a naturally occurring member of the isothiocyanate family, is produced from cruciferous vegetables, such as broccoli (22). SFN is an effective agent in the 
chemoprevention of chemically-induced breast $(23,24)$, colon (25) and stomach (26) cancers in rats. In a chemotherapeutic study, SFN drastically inhibited the growth of xenografts of human prostate cancer by oral administration (27) and breast cancer by intravenous injection (28). SFN suppresses the growth of cancer cells in vitro by inhibiting cell cycle progression (28-32) and/or causing apoptosis $(27,29,30)$ in T-cell leukemia, colon, breast and prostate cancer cells. In addition, it was reported that SFN induces $\mathrm{p} 21^{\text {WAFI/CIPI }}$ and $\mathrm{G}_{1^{-}}$and $\mathrm{G}_{2} / \mathrm{M}$-phase cell cycle arrest in human colon cancer cells. We previously reported that SFN up-regulates DR5 expression and the combined treatment with SFN and TRAIL-induced apoptosis in human osteosarcoma cells (33). However, in osteosarcoma cells, the anti-tumor effects of SFN were not reported in vivo.

In this study, we confirmed that SFN causes cell cycle arrest and apoptosis in vitro. Furthermore, we investigated the anti-tumor activity of SFN against osteosarcoma cells in vivo.

\section{Materials and methods}

Reagents. Sulforaphane (SFN) was purchased from LKT (St. Paul, MN). SFN was dissolved in DMSO. Equivalent amounts of DMSO were used as controls. The maximum volume $(\%)$ of DMSO in the assays was $0.1 \%$.

Cell culture. We used a human osteosarcoma cell line (MG63) and a murine osteosarcoma cell line (LM8), which was established from the murine Dunn osteosarcoma cell line and has high metastatic potential to the lungs (34). LM8 cells and human osteosarcoma MG63 cells were cultured in Dulbecco's modified Eagle's medium (DMEM) containing 10\% fetal bovine serum and incubated at $37^{\circ} \mathrm{C}$ in a humidified atmosphere of $5 \% \mathrm{CO}_{2}$.

Cell growth study. For the cell growth study, LM8 cells and MG63 cells were seeded at a density of $1 \times 10^{4}$ cells in a 12-well plate. Twenty-four hours after the seeding, SFN was added at various concentrations. From 24 to $48 \mathrm{~h}$ after the treatment, the number of viable cells were counted using a trypan blue dye exclusion test. The data are presented as the mean \pm SD of at least three independent experiments.

Analysis of cell cycle progression. Unsynchronized cells were exposed to SFN for $24 \mathrm{~h}$ and harvested from culture dishes. After washing with PBS, the cells were suspended in PBS containing $0.1 \%$ Triton $\mathrm{X}-100$, treated with RNase A and the nuclei were stained with propidium iodide (PI). DNA content was measured using a FACSCalibur flow cytometer with Cell Quest software (Becton Dickinson, Franklin Lakes, NJ). For all assays, 10,000 events were counted. The ModFit LT V2.0 software package (Verity Software, Topsham, ME) was used to analyse the data.

Western blot analysis. A protein extraction and Western blot analysis was performed as previously described (35), using a rabbit polyclonal anti-p21 WAFI/CIPI antibody (1:500; Santa Cruz Biotechnology, Santa Cruz, CA), a mouse monoclonal antiGAPDH (1:1000) antibody (Immunotech, Marseille, France) and a mouse monoclonal anti-pro-caspase-3 (1:10) antibody
(Immunotech, Marseille, France). Enhanced chemiluminescence (GE Science, Piscataway, NJ) was used for detection.

Detection of apoptosis. To analyse apoptosis, hypodiploid DNA (Sub-G1) populations were assayed using a FACSCalibur flow cytometer with Cell Quest software (Becton Dickinson) as previously described (36). For all assays, 10,000 events were counted and carried out in triplicate. The data were analysed using the Student's t-test. Differences were considered to be statistically significant from the controls for $\mathrm{p}<0.05$.

For the observation of nuclear morphology, cells grown in six-well plates were incubated with DMSO or SFN at $20 \mu \mathrm{M}$ for $48 \mathrm{~h}$. The cells were then fixed in methanol, incubated with 4'-diamino-2-phenylindole (DAPI) solution for $30 \mathrm{~min}$ in the dark and then analysed using a fluorescence microscope (Olympus, Tokyo, Japan) at $420 \mathrm{~nm}$.

Xenograft assay. Male Balb/C mice (Oriental Bio Service, Kyoto, Japan) were maintained according to the Institutional Animal Care Use Committee guidelines. LM8 cells were mixed in PBS and a suspension containing $10^{7}$ LM8 cells was administered to the right flank of mice via an s.c. injection. Mice were randomized into three groups of 5 mice/group. Twenty-four hours later, intraperitoneal injections of SFN (1 or $2 \mathrm{mg}$ in $0.1 \mathrm{ml} \mathrm{PBS}$ ) were performed 5 times/week. Control mice received an equal volume of the vehicle. Tumor volume was determined as previously described (37). Statistically significant differences in tumor volume between the control and the treated mice were assessed by the Student's t-test.

\section{Results}

SFN inhibited the growth of murine osteosarcoma LM8 cells. We investigated the effects of SFN on the growth of murine osteosarcoma LM8 cells. Fig. 1 shows the growth of LM8 cells in the presence of various concentrations of SFN. A dosedependent inhibition of cell growth was observed at concentrations of $5 \mu \mathrm{M}$ or more. Forty-eight hours after the addition of SFN, the growth of LM8 cells was inhibited to 71.3, 18.4 and $4.4 \%$ of the control level by 5, 10 and $20 \mu \mathrm{M} \mathrm{SFN}$, respectively (Fig. 1).

SFN arrested LM8 cells at the $G_{2} / M$ phase in the cell cycle progression and up-regulated $221^{\text {WAFI/CIPI }}$ expression. To elucidate the effect of SFN on the cell cycle progression of LM8 cells, the DNA content of nuclei of LM8 cells was measured by flow cytometric analysis. As shown in Fig. 2A, the FACS analysis revealed that a $24 \mathrm{~h}$ exposure to SFN increased the population of $\mathrm{G}_{2} / \mathrm{M}$ phase cells in a dose-dependent manner. LM8 cells at the $\mathrm{G}_{2} / \mathrm{M}$ phase increased from $13.3 \%$ in medium alone to $33.0 \%$ by treatment with $20 \mu \mathrm{M} \mathrm{SFN}$.

We examined the expression of the $\mathrm{p} 21^{\text {WAFI/CIPI }}$ protein after SFN treatment. In LM8 cells, as shown in Fig. 2B, we found that SFN increased the $\mathrm{p} 21^{\text {WAFI/CIPI }}$ protein expression in a dose-dependent manner using Western blotting.

SFN effectively induced apoptosis in LM8 cells. We investigated that SFN induces apoptosis in LM8 cells. Treatment 


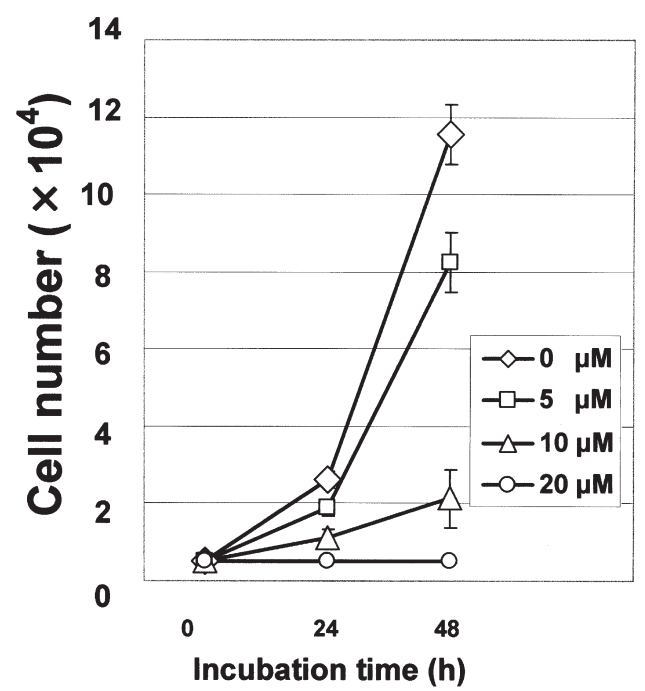

Figure 1. Effect of SFN on the growth of LM8. Twenty-four hours after seeding of LM8 cells, SFN at $5(\square), 10(\triangle)$, or $20(\bigcirc) \mu \mathrm{M}$ was added and the cell number was compared with a control culture with equivalent DMSO $(\diamond)$ by counting the cells using a trypan blue dye exclusion test. The values shown are means (bars, $S D)(n=3)$.

A.
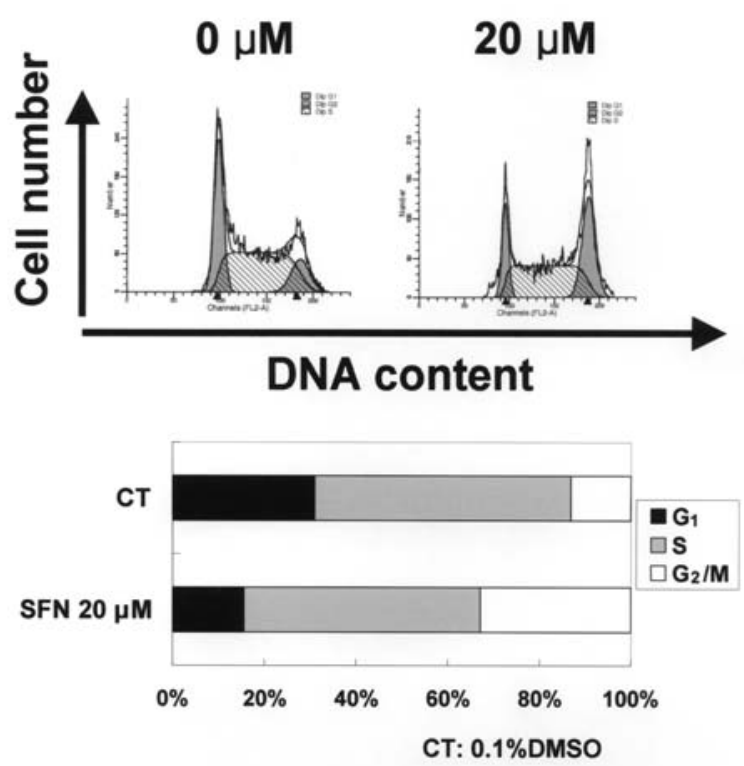

B.

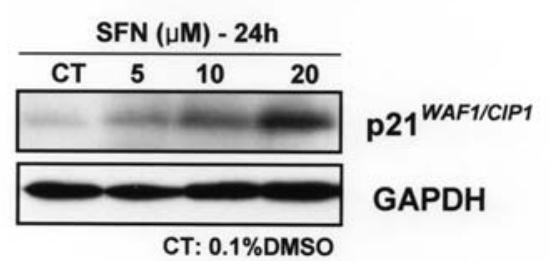

Figure 2. The effect of SFN on the cell cycle progression and up-regulation of $\mathrm{p} 21^{\text {WAFI/CIPI }}$ expression by SFN in LM8 cells. (A) LM8 cells were treated with or without $20 \mu \mathrm{M}$ SFN at the indicated concentrations for $24 \mathrm{~h}$. The DNA content of propidium iodide-stained nuclei was analysed by FACSCalibur flow cytometry as described in Materials and methods. The experiments were repeated to confirm the results. The percentage of cells in phases $\mathrm{G}_{1}$ (black), $\mathrm{S}$ (gray) and $\mathrm{G}_{2} / \mathrm{M}$ (white) was determined. (B) $\mathrm{SFN}$ upregulated the $\mathrm{p} 21^{\text {WAFI/CIPI }}$ protein expression. LM8 cells were treated with SFN at the indicated concentrations for $24 \mathrm{~h}$. Western blotting was then performed as described in Materials and methods. An anti-GAPDH antibody was used to confirm equal gel loading.

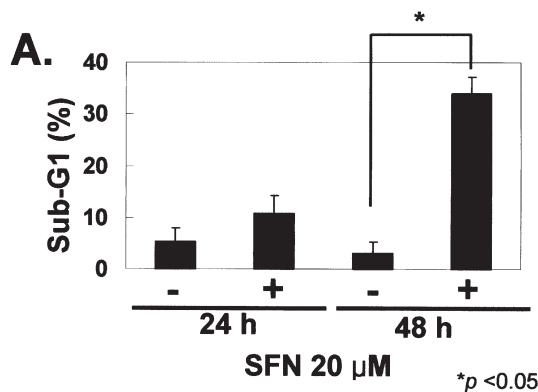

B.

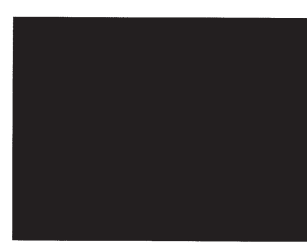

SFN $0 \mu M-48 h$

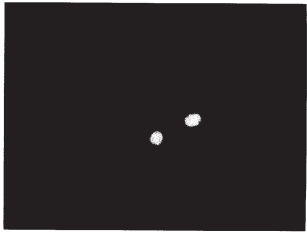

SFN $20 \mu M-48 h$
C.

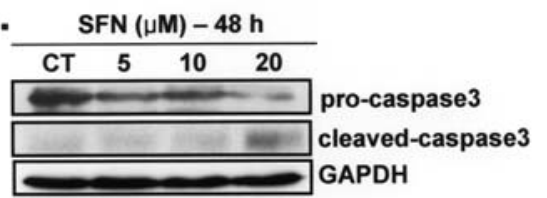

CT: 0.1\%DMSO

Figure 3. SFN induced apoptosis in LM8 cells. (A) LM8 cells were treated with or without $20 \mu \mathrm{M}$ SFN for the indicated periods. Apoptosis (Sub-G1) was determined by FACS analysis of the DNA content of propidium iodidestained nuclei as described in Materials and methods. Data are shown as means (bars, SD) $(\mathrm{n}=3) . * \mathrm{p}<0.05$. (B) DAPI staining of LM8 cells. LM8 cells were treated with or without $20 \mu \mathrm{M} \mathrm{SFN}$ for $48 \mathrm{~h}$ and then nuclear morphology was visualized using DAPI staining using a fluorescence microscope. (C) Caspase- 3 was activated by SFN. LM8 cells were treated with SFN, at the indicated concentrations for $48 \mathrm{~h}$. Caspase-3 was then assessed by Western blotting. An anti-GAPDH antibody was used to confirm equal gel loading.

with $20 \mu \mathrm{M}$ SFN for $24 \mathrm{~h}$ weakly induced apoptosis in LM8 cells. However, treatment with $20 \mu \mathrm{M} \mathrm{SFN}$ for $48 \mathrm{~h}$ effectively induced apoptosis in LM8 cells (Fig. 3A).

Fig. 3B shows the morphological features of LM8 cells that exhibited the characteristic features of apoptosis including chromatin condensation.

To confirm the effect of SFN on the activation of caspases, we carried out a Western blot analysis. As shown in Fig. 3C, SFN caused the cleavage and activation of caspase-3. These results indicate that the SFN-mediated cell death occurred in a caspase-dependent manner.

SFN induced a $G_{2} / M$ phase cell cycle arrest and up-regulated p21 $1^{\text {WAFI/CIPI }}$ expression in human osteosarcoma MG63 cells in a p53-independent manner. We investigated the effects of SFN on the growth and the cell cycle of human osteosarcoma MG63 cells. Fig. 4A shows that a dose-dependent inhibition of the cell growth was observed at concentrations of $5 \mu \mathrm{M}$ or more. FACS analysis revealed that a $24 \mathrm{~h}$ exposure to SFN increased the population of $\mathrm{G}_{2} / \mathrm{M}$ phase cells in a dosedependent manner (Fig. 4B). We examined the expression of the $\mathrm{p} 21^{\text {WAFI/CIPI }}$ protein after SFN treatment and found that the SFN increased the $\mathrm{p} 21^{\text {WAFI/CIPI }}$ protein expression in human osteosarcoma MG63 cells in a dose-dependent manner using 
A.

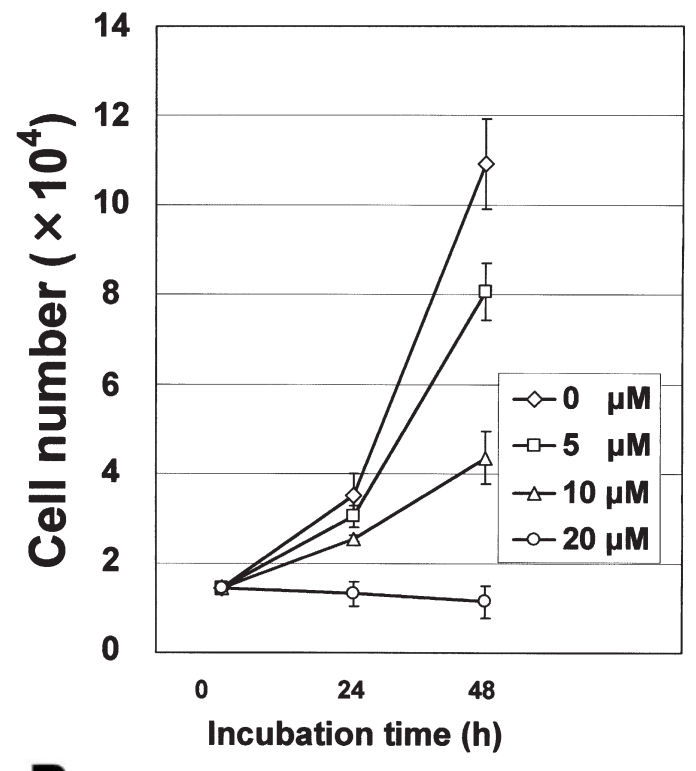

B
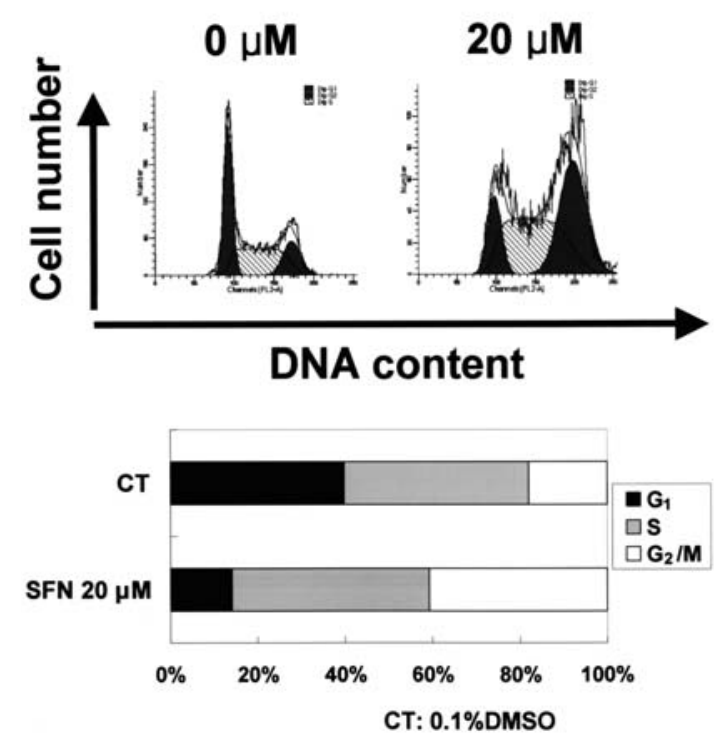

C

SFN $(\mu M)-24 h$

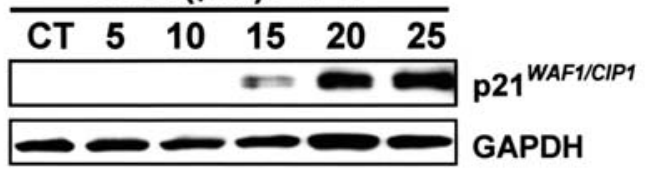

CT: $0.1 \%$ DMSO

Figure 4. $\mathrm{p} 21^{\text {WAFI/CIPI }}$ induction by $\mathrm{SFN}$ in a p53-independent manner in human osteosarcoma MG63 cells. (A) Twenty-four hours after seeding of MG63 cells, SFN at $5(\square), 10(\triangle), 20(\bigcirc) \mu \mathrm{M}$ was added and the cell number was compared with a control culture with equivalent DMSO $(\diamond)$ by counting the cells using a trypan blue dye exclusion test. The values shown are means (bars, SD) (n=3). (B) MG63 cells were treated with or without $20 \mu \mathrm{M}$ SFN for $24 \mathrm{~h}$. The DNA content of propidium iodide-stained nuclei was analysed by FACSCalibur flow cytometry as described in Materials and methods. The experiments were repeated to confirm the results. The cell percentage in phases $\mathrm{G}_{1}$ (black), $\mathrm{S}$ (gray) and $\mathrm{G}_{2} / \mathrm{M}$ (white) was determined. (B) SFN upregulated $\mathrm{p} 21^{\text {WAFI/CIPI }}$ protein expression in a p53-independent manner. MG63 cells were treated with SFN at the indicated concentrations for $24 \mathrm{~h}$. Western blotting was then performed as described in Materials and methods. An anti-GAPDH antibody was used to confirm equal gel loading.

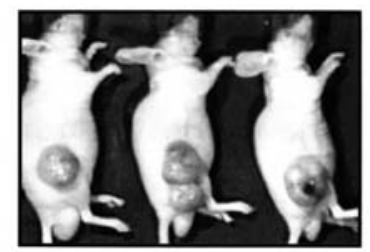

CT

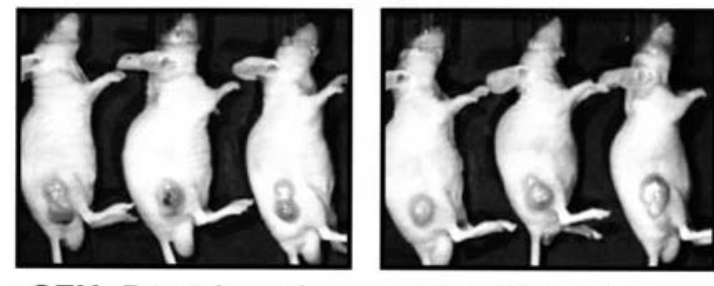

SFN $5 \mathrm{mg} /$ week

SFN $10 \mathrm{mg} /$ week

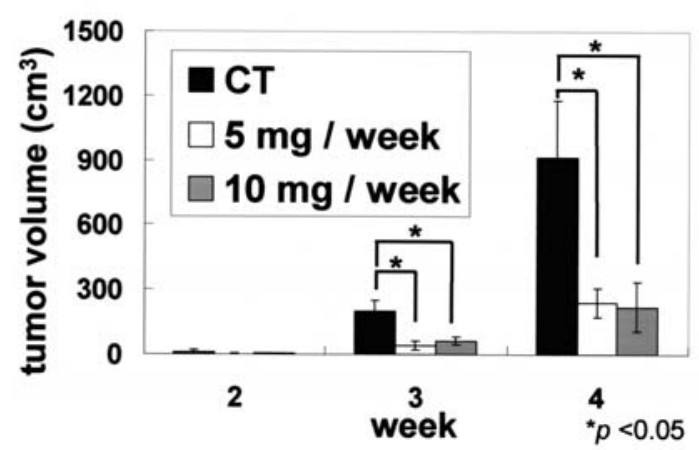

Figure 5. Intraperitoneal administration of SFN inhibits LM8 tumor xenograft growth in syngeneic Balb/C mice. Each mouse was implanted with ten million LM8 cells mixed in PBS on the right flank via a subcutaneous injection. After $24 \mathrm{~h}$, mice were treated with intraperitoneal injections of saline (control group) or SFN (1 or $2 \mathrm{mg}$ in $0.1 \mathrm{ml} \mathrm{PBS}$ ) for 5 days/week for 4 weeks. Mean tumor volume/mouse $\left(\mathrm{mm}^{3}\right)$ was significantly reduced in SFN-treated mice, as compared with controls. Statistical significance of different tumor volume or body weight between the control and the treated mice was assessed by the Student's t-test.

Western blotting (Fig. 4C). These findings showed that SFN induced a $\mathrm{p} 21^{\text {WAFI/CIPI }}$ protein expression through a p53independent pathway because p53 is inactivated in MG63 cells.

Intraperitoneal administration of SFN inhibits growth of LM8 xenografts in vivo. Prior to clinical trials, it is important that the in vivo efficacy of potential anticancer agents is determined in an animal model. Therefore, we performed an in vivo study to determine whether SFN administration inhibits the growth of LM8 xenografts in nude mice. As shown in Fig. 5, SFN treatment caused a significant inhibition of LM8 xenograft growth. Four weeks after starting therapy, LM8 xenografts of BALB/C mice injected i.p. with SFN (5 mg/week) were smaller $(73.8 \%$ less in mass) than vehicle-treated controls (Fig. 5). Similarly, the average tumor volumes in SFN (10 mg week) -treated mice were $75.8 \%$ lower than those of control mice. No remarkable signs of toxicity were observed following SFN administration.

\section{Discussion}

Previous studies revealed that SFN is a potent inhibitor of chemically-induced cancer in animals (23-26). Some studies 
reported that SFN effectively suppressed cancer xenografts in mice $(27,28)$. These reports indicated that SFN may be an attractive compound for molecular-targeting chemotherapy or chemoprevention for malignant tumors. The main objective of the present study was to evaluate anti-tumor efficacy and the mechanisms of SFN in osteosarcoma cells in the culture and to translate the in vitro findings in to an in vivo preclinical osteosarcoma model.

Our study revealed that SFN induces cell growth inhibition via cell cycle arrest specifically at the $G_{2} / M$ phase in murine osteosarcoma LM8 cells in culture studies. SFN was reported to induce either a $G_{1}$ arrest or $\mathrm{G}_{2} / \mathrm{M}$ arrest in various cancer cell lines. Some studies reported that SFN induces $\mathrm{G}_{1^{-}}$and $\mathrm{G}_{2} / \mathrm{M}$-phase cell cycle arrest through the induction of the p21 $1^{\text {WAFI/CIPI }}$ expression $(31,38)$. In this study, we confirmed that SFN induced the p $21^{\text {WAFI/CIPI }}$ expression and $\mathrm{G}_{2} / \mathrm{M}$-phase cell cycle arrest in osteosarcoma cells.

We also found that SFN induces cell cycle arrest in human osteosarcoma MG63 cells through the p53-independent activation of $\mathrm{p} 21^{W A F I / C I P I}$. Recent studies reported that conventional anti-osteosarcoma agents such as doxorubicin, cisplatin and etoposide have anti-tumor effects mainly in a p53-dependent manner $(39,40)$. Therefore, the p53independent pathway of the $\mathrm{p} 21^{\text {WAFI/CIPI }}$ induction by SFN may be effective for the chemotherapy of osteosarcoma with resistance to conventional agents due to the inactivated p53.

Several studies reported that SFN induces apoptosis through the mitochondrial apoptotic pathway, via the up- or down-regulation of Bax, Bak, XIAP and Bcl-2 expression (27-30,41). In addition, recent reports revealed the death receptor pathway of SFN $(33,42)$. In these reports, caspase- 3 was activated by the mitochondrial and death receptor apoptotic pathways. In this study, SFN-induced cell death was apoptotic and accompanied by caspase- 3 activation in LM8 cells. We reported that SFN up-regulates DR5 expression and sensitizes TRAIL-induced apoptosis in human osteosarcoma cells (33). Therefore, rather than as a single agent, the combined treatment using SFN with TRAIL and/or other anti-tumor agents may be more effective for chemotherapy against osteosarcoma.

Based on the encouraging in vitro anti-tumor efficacy of SFN against osteosarcoma, we found that the intraperitoneal administration of SFN (5 and $10 \mathrm{mg} /$ week) significantly retarded the growth of LM8 xenografts to $<30 \%$ controls in a preclinical animal model without causing any toxicity. Singh et al reported that oral administration of SFN $(5.6 \mu \mathrm{mol}, 3$ times/week) significantly inhibited the growth of xenografts of human prostate cancer to $\sim 50 \%$ of the mass of vehicletreated controls (27). Jackson and Singletary reported that daily intravenous injection of SFN ( $15 \mathrm{nmol} /$ day for 13 days) significantly affected smaller xenografts of human breast cancer to $\sim 40 \%$ of the mass of vehicle-treated controls (28). In osteosarcoma cells, our findings in this study provide in vivo evidence for the efficacy of SFN against the advanced growth of tumors.

$\mathrm{SFN}$ is a food factor contained in vegetables. Ye et al reported the human plasma concentrations to reach only $2 \mu \mathrm{M}$ after consuming SFN-rich broccoli sprouts (43). However, $\mathrm{Hu}$ et al reported that plasma concentrations reached $20 \mu \mathrm{M}$ after oral administration of SFN in rats (44). After the administration of purified SFN, the murine plasma concentrations in this in vivo study may reach a concentration used in our in vitro study. In the clinic, we will use purified SFN as an anti-tumor agent for osteosarcoma cells.

Recently, a histone deacetylase (HDAC) inhibitory activity of SFN was reported $(45,46)$. Our previous study showed that histone deacetylase inhibitors (HDACIs) such as trichostatin A (TSA), sodium butyrate and suberoylanilide hydoxamic acid (SAHA) induce the $\mathrm{p} 21^{\text {WAFI/CIPI }}$ protein in malignant tumor cells. Though we examined an HDAC inhibitory activity of SFN by the detection of acetylated histone $\mathrm{H} 4$ using Western blot analysis in MG63 cells, we did not detect an increase of acetylated histone $\mathrm{H} 4$ after treatment with SFN (data not shown). This result suggests that SFN may induce the p21 $1^{\text {WAFI/CIPI }}$ expression through a mechanism different from the function of HDACIs in osteosarcoma MG63 cells.

In conclusion, our results showed that SFN inhibits cell growth and induces cell cycle arrest and apoptosis in murine osteosarcoma cells. Furthermore, findings in xenograft studies translate the anti-tumor effects in a preclinical osteosarcoma model. These results raise the possibility that treatment with $\mathrm{SFN}$ is promising for the chemotherapy of osteosarcoma.

\section{Acknowledgements}

This study was supported by a Grant-in-aid (18791050) for Scientific Research from the Ministry of Education, Culture, Sports, Science and Technology of Japan and by the Takeda Science Foundation.

\section{References}

1. Unni KK: Dahlin's Bone Tumors. In: General Aspects and Data on 11,087 Cases. 5th Edition, Lippincott-Raven, Philadelphia, pp143-183, 1996.

2. Meyers PA, Heller G, Healey J, Huvos A, Lane J, Marcove R, Applewhite A, Vlamis V and Rosen G: Chemotherapy for nonmetastatic osteogenic sarcoma: the Memorial SloanKettering experience. J Clin Oncol 10: 5-15, 1992.

3. Bramwell VH, Burgers M, Sneath R, Souhami R, van Oosterom AT, Voute PA, Rouesse J, Spooner D, Craft AW, Somers R, Pringle J, Malcolm AJ, Eijken J, Thomas D, Uscinska B, Machin D and Glabbeke M: A comparison of two short intensive adjuvant chemotherapy regimens in operable osteosarcima of limbs in children and young adults: the first study of the European Osteosarcoma Intergroup. J Clin Oncol 10: 1579-1591, 1992.

4. Patel SJ, Lynch JW Jr, Jhonson T, Carroll RR, Schumacher C, Spanier S and Scarborough M: Dose-intense ifosfamide/ doxorubicin/cisplatin based chemotherapy for osteosarcoma in adults. Am J Clin Oncol 25: 489-495, 2002.

5. Zalupski MM, Rankin C, Ryan JR, Lucas DR, Muler J, Lanier KS, Budd GT, Biermann JS, Meyers FJ and Antman K: Adjuvant therapy of osteosarcoma - A phase II trial: Southwest Oncology Group study 9139. Cancer 100: 818-825, 2004.

6. Marina NM, Pratt CB, Rao BN, Shema SJ and Meyer WH: Improved prognosis of children with osteosarcoma metastatic to the lung(s) at the time of diagnosis. Cancer 70: 2722-2727, 1992.

7. Voute PA, Souhami RL, Nooij M, Somers R, Cortes-Funes H, van der Eijken JW, Pringle J, Hogendoorn PC, Kirkpatrick A, Uscinska BM, van Glabbeke M, Machin D and Weeden S: A phase II study of cisplatin, ifosfamide and doxorubicin in operable primary, axial skeletal and metastatic osteosarcoma. European Osteosarcoma Intergroup (EOI). Ann Oncol 10: 1211-1218, 1999.

8. Ozaki T, Flege S, Kevric M, Lindner N, Maas R, Delling G, Schwarz R, von Hochstetter AR, Salzer-Kuntschik M, Berdel WE, Jurgens H, Exner GU, Reichardt P, Mayer-Steinacker R, Ewerbeck V, Kotz R, Winkelmann W and Bielack SS: Osteosarcoma of the pelvis: experience of the Cooperative Osteosarcoma Study Group. J Clin Oncol 21: 334-341, 2003. 
9. Bacci G, Briccoli A, Rocca M, Ferrari S, Donati D, Longhi A, Bertoni F, Bacchini P, Giacomini S, Forni C, Manfrini M and Galletti S: Neoadjuvant chemotherapy for osteosarcoma of the extremities with metastases at presentation: recent experience at the Rizzoli Institute in 57 patients treated with cisplatin, doxorubicin and a high dose of methotrexate and ifosfamide. Ann Oncol 14: 1126-1134, 2003.

10. Patel SR, Papadopolous N, Raymond AK, Donato M, Seong CM, Yasko AW, Lewis VO, Lin PP, Champlin R and Benjamin RS: A phase II study of cisplatin, doxorubicin and ifosfamide with peripheral blood stem cell support in patients with skeletal osteosarcoma and variant bone tumors with a poor prognosis. Cancer 101: 156-163, 2004.

11. Takeshita H, Gebhardt MC, Springfield DS, Kusuzaki K and Mankin HJ: Experimental models for the study of drug resistance in osteosarcoma: P-glycoprotein-positive, murine osteosarcoma cell lines. J Bone Joint Surg 78-A: 366-375, 1996.

12. Hirata M, Kusuzaki K, Takeshita H, Hashiguchi S, Hirasawa Y and Ashihara T: Drug resistance modification using pulsing electromagnetic field stimulation for multidrug resistant mouse osteosarcoma cell line. Anticancer Res 21: 317-320, 2001.

13. Webster KR: The therapeutic potential of targeting the cell cycle. In: Expert Opin Investig Drugs 7: 865-887, 1998.

14. Schwartz GK and Shah MA: Targeting the cell cycle: a new approach to cancer therapy. J Clin Oncol 23: 9408-9421, 2005.

15. Harper JW, Adami GR, Wei N, Keyomarsi K and Elledge SJ: The p21 Cdk-interacting protein Cip1 is a potent inhibitor of $\mathrm{G}_{1}$ cyclin-dependent kinases. Cell 75: 805-816, 1993.

16. Dulic V, Kaufmann WK, Wilson SJ, Tlsty TD, Lees E, Harper JW, Elledge SJ and Reed SI: p53-dependent inhibition of cyclindependent kinase activities in human fibroblasts during radiation-induced $\mathrm{G}_{1}$ arrest. Cell 76: 1013-1023, 1994.

17. Ando T, Kawabe T, Ohara H, Ducommun B, Itoh M and Okamoto T: Involvement of the interaction between p21 and proliferating cell nuclear antigen for the maintenance of $\mathrm{G}_{2} / \mathrm{M}$ arrest after DNA damage. J Biol Chem 276: 42971-42977, 2001.

18. Dash BC and El-Deiry WS: Phosphorylation of p21 in $\mathrm{G}_{2} / \mathrm{M}$ promotes cyclin B-Cdc2 kinase activity. Mol Cell Biol 25: 3364-3387, 2005.

19. Matsumoto T, Sowa Y, Ohtani-Fujita N, Tamaki T, Takenaka T, Kuribayashi K and Sakai T: p53-independent induction of WAF1/Cip1 is correlated with osteoblastic differentiation by vitamin $\mathrm{D}_{3}$. Cancer Lett 129: 61-68, 1998.

20. Gartel AL, Serfas MS and Tyner AL: p21-negative regulator of the cell cycle. Proc Soc Exp Biol Med 213: 138-149, 1996.

21. MacKeigan JP, Murphy LO and Bleins J: Sensitized RNAi screen of human kinases and phosphatases identifies new regulators of apoptosis and chemoresistance. Nat Cell Biol 7: 591-600, 2005.

22. Zhang Y, Talalay P, Cho CG and Posner GH: A major inducer of anticarcinogenic protective enzymes from broccoli: isolation and elucidation of structure. Proc Natl Acad Sci USA 89: 2399-2403, 1992.

23. Zhang Y, Kensler TW, Cho CG, Posner GH and Talalay P: Anticarcinogenic activities of sulforaphane and structurally related synthetic norbornyl isothiocyanates. Proc Natl Acad Sci USA 91: 3147-3150, 1994

24. Fahey JW, Zhang Y and Talalay P: Broccoli sprouts: an exceptionally rich source of inducers of enzymes that protect against chemical carcinogens. Proc Natl Acad Sci USA 94: 10367-10372, 1997.

25. Chung FL, Conaway CC, Rao CV and Reddy BS: Chemoprevention of colonic aberrant crypt foci in Fischer rats by sulforaphane and phenetyl isothiocyanate. Carcinogenesis 21 : 2287-2291, 2000.

26. Fahey JW, Haristoy X, Dolan PM, Kensler TW, Scholtus I, Stephenson KK, Talalay P and Lozniewski A: Sulforaphane inhibits extracellular, intracellular and antibiotic-resistant strains of Helicobacter pylori and prevents benzo (a) pyrene-induced stomach tumors. Proc Natl Acad Sci USA 99: 7610-7615, 2002.

27. Singh AV, Xiao D, Lew KL, Dhir R and Singh SV: Sulforaphane induces caspase-mediated apoptosis in cultured PC-3 human prostate cancer cells and retards growth of PC- 3 xenografts in vivo. Carcinogenesis 25: 83-90, 2004.

28. Jackson SJT and Singletary KW: Sulforaphane: a naturally occurring mammary carcinoma mitotic inhibitor, which disrupts tubulin polymerization. Carcinogenesis 25: 219-227, 2004.
29. Gamet-Payrastre L, Li P, Lumeau S, Cassar G, Dupont MA, Chevolleau S, Gasc N, Tulliez J and Terce F: Sulforaphane, a naturally occurring isothiocyanate, induces cell cycle arrest and apoptosis in HT29 human colon cancer cells. Cancer Res 60: 1426-1433, 2000.

30. Fimognari C, Nusse M, Cesari R, Iori R, Cantelli-Forti G and Hrelia P: Growth inhibition, cell-cycle arrest and apoptosis in human T-cell leukemia by the isothiocyanate sulforaphane. Carcinogenesis 23: 581-586, 2002.

31. Parnaud G, Li P, Cassar G, Rouimi P, Tulliez J, Combaret L and Gamet-Payrastre L: Mechanism of sulforaphane-induced cell cycle arrest and apoptosis in human colon cancer cells. Nutr Cancer 48: 198-206, 2004.

32. Singh SV, Herman-Antosiewicz A, Singh AV, Lew KL, Srivastava SK, Kamath R, Brown KD, Zhang L and Baskaran R: Sulforaphane-induced $\mathrm{G}_{2}-\mathrm{M}$ phase cell cycle arrest involves checkpoint kinase 2-mediated phosphorylation of cell division cycle 25C. J Biol Chem 279: 25813-25822, 2004.

33. Matsui TA, Sowa Y, Yoshida T, Murata H, Horinaka M, Wakada M, Nakanishi R, Sakabe T, Kubo T and Sakai T: Sulforaphane enhances TRAIL-induced apoptosis through the induction of DR5 expression in human osteosarcoma cells. Carcinogenesis 27: 1768-1777, 2006.

34. Asai T, Ueda T, Itoh K, Yoshioka K, Aoki Y, Mori S and Yoshikawa H: Establishment and characterization of a murine osteosarcoma cell line (LM8) with high metastatic potential to the lung. Int J Cancer 76: 418-422, 1998.

35. Nakano K, Mizuno T, Sowa Y, Orita T, Yoshino T, Okuyama Y, Fujita T, Ohtani-Fujita N, Matsukawa Y, Tokino T, Yamagishi H, Oka T, Nomura H and Sakai T: Butyrate activates the WAF1/ Cip1 gene promoter through Sp1 sites in a p53-negative human colon cancer cell line. J Biol Chem 272: 22199-22206, 1997.

36. Nakata S, Yoshida T, Horinaka M, Shiraishi T, Wakada M and Sakai T: Histone deacetylase inhibitors up-regulate death receptor 5/TRAIL-R2 and sensitize apoptosis induced by TRAIL/APO2-L in human malignant tumor cells. Oncogene 23: 6261-6271, 2004.

37. Singh SV, Mohan RR, Agarwal R, Benson PJ, Hu X, Rudy MA, Xia H, Katoh A, Srivastava SK, Mukhtar H, Gupta V and Zaren HA: Novel anti-carcinogenic activity of an organosulfide from garlic: inhibition of H-RAS oncogene-transformed tumor growth in vivo by diallyl disulfide is associated with inhibition of p21H-ras processing. Biochem Biophys Res Commun 225: 660-665, 1996.

38. Shen G, Xu C, Chen C, Hebbar V and Kong AN: p53-independent G1 cell cycle arrest of human colon carcinoma cells HT-29 by sulforaphane is associated with induction of p21CIP1 and inhibition of expression of cyclin D1. Cancer Chemother Pharmacol 57: 317-327, 2006.

39. Lowe SW, Ruley HE, Jacks T and Housman DE: p53-dependent apoptosis modulates the cytotoxicity of anticancer drugs. Cell 74: 957-967, 1993.

40. Wang LH, Okaichi K, Ihara M and Okumura Y: Sensitivity of anticancer drugs in Saos-2 cells transfected with mutant p53 varied with mutation point. Anticancer Res 18: 321-325, 1998.

41. Choi S and Singh SV: Bax and Bak are required for apoptosis induction by sulforaphane, a cruciferous vegetable-derived cancer chemopreventive agent. Cancer Res 65: 2035-2043, 2005.

42. Kim K, Kim EH, Eom YW, Kim WH, Kwon TK, Lee SJ and Choi KS: Sulforaphane sensitizes tumor necrosis factor-related apoptosis-inducing ligand (TRAIL)-resistant hepatoma cells to TRAIL-induced apoptosis through reactive oxygen speciesmediated up-regulation of DR5. Cancer Res 66: 1740-1750, 2006.

43. Ye L, Dinkova-Kostova AT, Wade KL, Zhang Y, Shapiro TA and Talalay P: Quantitative determination of dithiocarbamates in human plasma, serum, erythrocytes and urine: pharmacokinetics of broccoli sprout isothiocyanates in humans. Clin Chim Acta 316: 43-53, 2002.

44. Hu R, Hebbar V, Kim BR, Chen C, Winnik B, Buckley B, Soteropoulos $\mathrm{P}$, Tolias $\mathrm{P}$, Hart RP and Kong $\mathrm{AN}$ : In vivo pharmacokinetics and regulation of gene expression profiles by isothiocyanate sulforaphane in the rat. J Pharmacol Exp Ther 310: 263-271, 2004

45. Myzak MC, Karplus PA, Chung FL and Dashwood RH: A novel mechanism of chemoprotection by sulforaphane: inhibition of histone deacetylase. Cancer Res 64: 5767-5774, 2004

46. Myzac MC, Hardin K, Wang R, Dashwood RH and Ho E: Sulforaphane inhibits histone deacetylase activity in BPH-1, $\mathrm{LnCaP}$ and PC-3 prostate epithelial cells. Carcinogenesis 27: 811-819, 2006. 